УДК 666.3\7

Огороднік I.B.

НДЦ ТК ТОВ «Фірма Пориекс-ВРБТ»

\title{
ОСОБЛИВОСТІ ВИРОБНИЦТВА КЕРАМІЧНОЇ ЦЕГЛИ ДЛЯ ОБЛИЧКУВАННЯ ФАСАДІВ СВІТЛИХ ТОНІВ
}

В статье представлень особенности технологии производства керамического кирпича для обличовки фасадов светлых тонов. Рассмотрен химический состав компонентов керамических масс. Представлены составы масс с различными осветляющими компонентами и параметры производства облищовочной керамики светльх тонов.

У статті подані особливості технології виробництва керамічної цегли для обличкування фасадів світлого тону. Розглянуто хімічний склад компонентів керамічних мас. Подані розроблені склади мас з різними компонентами, щзо освітлюють шихту та параметри виробництва обличкувальної кераміки світлого тону.

The article features the technology of light colored ceramic bricks production for facades cladding. The chemical compositions of ceramic masses components have been defined in the article. Developed masses compositions with different components, illuminating the charge, were submitted in the frame of article. Parameters for light colored ceramics bricks production were considered in the frame of article.

\section{Вступ}

Керамічні лицьові вироби дозволяють отримувати різноманітні архітектурні рішення в сучасному житловому будівництві. Великі можливості в цьому напрямку 3'являються при використанні лицьової та клінкерної керамічної цегли об'ємного фарбування різної кольорової палітри. Відмінна перевага такої цегли порівняно 3 двошаровою, ангобованою та поливаною є іiї довговічність за рахунок однорідного тіла цегли. Крім цього, об'ємне фарбування кераміки не потребує додаткового технологічного обладнання.

\section{Стан питання}

Науково-дослідні розробки, з ціллю об’ємного фарбування керамічних виробів, проводяться протягом багатьох років. Отримання різних кольорів керамічної плитки і цегли шляхом додавання до легкоплавких глин оксидів марганцю, заліза, хрому, титану та 
інших подано в багатьох публікаціях [1 - 6].

Сьогодні на ринку будівельних матеріалів найбільшим попитом користується цегла світлих відтінків.

Лицьова керамічна цегла в більшості виготовляється 3 червоновипальних легкоплавких глин. Відомим способом отримання світлої цегли (від кремового до жовтого кольору) 3 червоновипальної легкоплавкої глини $\epsilon$ комбінування світловипальною тугоплавкою глиною [1]. Недоліком цього способу $є$ важкість досягнення в виробничих умовах високої однорідності керамічної маси при змішуванні глин різної густини. Крім цього, не завжди виробники цегли мають можливість експлуатації глинистих кар'єрів з різною сировиною.

Для отримання світлої цегли 3 червоновипальної легкоплавкої глини використовують додатки диоксиду титану та додатки карбонатвмістких компонентів. Для отримання керамічної цегли сіро-жовтого, світло-жовтого, світло пісочного кольорів додають диоксид титану в кількості 5-10 \%. Світлу окраску с додатками диоксиду титану можна отримати в окремих випадках при випалі в окисному середовищі при збільшенні собівартості цегли [2].

Відомим способом отримання світлої лицьової цегли 3 червоновипальних легкоплавких глин є додаток від 15-50 \% карбонатної добавки у вигляді доломіту [3].

Більш універсальним способом отримання цегли світлих тонів є добавка в шихту тонкомолотої крейди в кількості від 15 до 30 \%. Це дає можливість отримати цеглу від морквяного, світло-рожевого до світло-жовтого кольору [2, 4 - 5].

Освітлення керамічного черепку карбонатами визначається в основному утворенням в процесі випалу залізовмістких мінералів, сполучаючи оксиди заліза двухкальцієвого фериту (2 $\mathrm{CaO}_{2} \mathrm{Fe}_{2} \mathrm{O}_{3}$ ) та мелиту, твердого розчину геленина $\left(2 \mathrm{CaO} \cdot \mathrm{Al}_{2} \mathrm{O}_{3} \cdot \mathrm{SiO}_{2}\right)$ та залізистого окерманіту $\left(2 \mathrm{CaO} \cdot \mathrm{FeO} \cdot 2 \mathrm{SiO}_{2}\right)$.

Різними дослідженнями встановлено, що для більш інтенсивного освітлення черепку із червоновипальної глини необхідно збільшення температури випалу виробів на 30-40 ${ }^{\circ} \mathrm{C}$, збільшення питомої поверхні карбонатних добавок.

Дослідниками [6] розроблено склад та спосіб виробництва лицьової цегли світложовтого та кремового кольорів на основі червоновипальної глини шляхом сумісного сухого помелу 15-90 \% глини с карбонатною добавкою у співвідношенні 1:1-3:1 до тонкості помелу з остатком на ситі 006 не більше ніж 10 \% та наступним змішуванням тонкодисперсного глинисто-карбонатного порошку з глиною, що залишилася. Недоліком даного способу $є$ необхідність гомогенізації суміші зволоженої глини та сухої тонкомолотої глинокарбонатної добавки.

Недоліком використання карбонатвмістких матеріалів (вапна, крейди, доломітової 
муки) є - при збільшенні кількості карбонатвмістких додатків - зменшення міцності на стиск та збільшення водопоглинення лицьової цегли

Таким чином, найбільш ефективним додатком, що освітлює червоновипальну глину при виробництві керамічної лицьової цегли є карбонатовмістні матеріали. Але при використанні їх в якості додатку можливо отримати вироби світлих тонів, але при цьому знижується якість лицьової цегли. Це питання так і залишилось технічно не вирішеним.

Автори [7] розробили керамічну масу для виготовлення керамічних виробів світлих тонів наступного складу: глина - 50 - 60\%; мергель -30 - $35 \%$, воластоніт - 10 - 15\%. Отримання світловипальної цегли полягає в наступному: на першому етапі виготовляють мінеральну добавку шляхом змішування та подрібнювання карбонатної добавки (мергелю) та добавки, що зміцнює цеглу воластонітового концентрату в кульовому млині. Шлікер характеризується густиною 1,70-1,72 г см² $^{2}$. Для забезпечення рідко текучого стану карбонатної суспензії вводиться додатково суміш рідкого скла та кальцинованої соди у співвідношенні 1:2. Потім цю суміш змішують 3 легкоплавкою червоновипальною глиною, яку додатково висушують у сушильному барабані, формують пластичним способом формування, висушують та випалюють при температурі 1020 - $1030^{\circ} \mathrm{C}$. При випалі на $1020{ }^{\circ} \mathrm{C}$ в тунельній печі вироби характеризуються міцністю на стиск - 35,5 36,3 МПа, при водопоглиненні - 13,5 - 13,9 \% та морозостійкості більше 35 циклів. Колір виробів світло-жовтий та кремовий.

Недоліком даного способу є виготовлення мінеральної добавки в кульовому млині, що потребує додаткового використання електролітів, тому що $\mathrm{CaO} €$ коагулянтом. Крім того, при змішуванні шлікеру 3 сухою глиною виникає нерівномірність перемішування суміші. Наслідком цього є різний тон лицьової цегли. Використання сушильного барабану для сушки шихти збільшує енерговитрати на виробництво цегли.

Перед керамічною промисловістю гостро стоїть задача зниження енергоємності виробництва. В зв'язку з цим дуже важливо досягти необхідні фізико-технічні та архітектурні властивості виробів при максимально можливому зниженні енерговитрат на виробництво.

\section{Експериментальна частина}

Зав досліджень була розробка технології виробництва високоякісної керамічної цегли для обличкування фасадів світлого тону на основі червоновипальної глини 3 комплексним використанням освітлюючого компоненту та біловипальних гідрослюдистокаолінітових глин. Вибір сировини обумовлено наявністю різної кількості освітлюючих оксидів, таких як $\mathrm{CaO}$, та $\mathrm{CaCO}_{3}$ та різної кількості оксидів, що фарбуют $\left(\mathrm{Fe}_{2} \mathrm{O}_{3}\right.$ та $\left.\mathrm{MnO}\right)$ вихідний матеріал. Хімічний склад сировини, що використовувалась для розробки керамічних мас, подано в таблиці 1. 
它

\begin{tabular}{|c|c|c|c|c|c|c|}
\hline \multicolumn{2}{|c|}{$\frac{2}{2}$} & $\frac{?}{6}$ & to & $\begin{array}{l}0 \\
\text { ñ } \\
0\end{array}$ & & $\begin{array}{l}n \\
n \\
\tilde{n} \\
n\end{array}$ \\
\hline \multirow{15}{*}{ 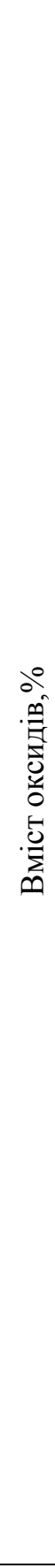 } & 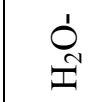 & $\frac{\circ}{0}$ & $\stackrel{8}{\circ}$ & $\underset{-}{8}$ & & 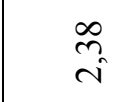 \\
\hline & $\bar{U}$ & $\begin{array}{l}\hat{8} \\
0 \\
0\end{array}$ & 8 & $\stackrel{8}{\circ}$ & 1 & $\sigma_{0}$ \\
\hline & 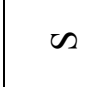 & $\begin{array}{l}0 \\
0 \\
0\end{array}$ & $\ddot{0}$ & $\mathbb{8}_{0}$ & & $\begin{array}{l}\infty \\
0 \\
0 \\
0\end{array}$ \\
\hline & $\overbrace{0}^{\infty}$ & $\frac{ \pm}{0}$ & $\begin{array}{l}n \\
0 \\
0\end{array}$ & $\begin{array}{ll}\dot{1} & 0 \\
0 & 0 \\
0 & 0 \\
0\end{array}$ & ' & $\frac{n}{0}$ \\
\hline & 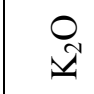 & 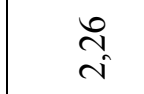 & $\begin{array}{l}\infty \\
\stackrel{n}{\sim}\end{array}$ & $\stackrel{1}{a} 0$ & I & $\tilde{o}_{0}^{0}$ \\
\hline & $\begin{array}{l}0 \\
\text { Z } \\
\text { Z }\end{array}$ & $\frac{a}{i}$ & $\frac{m}{0}$ & 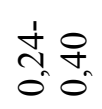 & ' & $\begin{array}{l}\text { సે } \\
\text { రิ }\end{array}$ \\
\hline & $\bigcup_{\substack{\infty \\
\Sigma}}^{\infty}$ & ' & ' & & $\stackrel{0}{m}$ & ' \\
\hline & $e_{0}^{\infty}$ & ' & ' & , & $\begin{array}{l}\dot{1} \infty \\
\infty \\
\infty \\
\dot{\sigma} \sigma\end{array}$ & ' \\
\hline & రి & $\frac{a}{i}$ & $\tilde{n}_{0}$ & 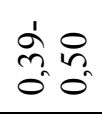 & ' & $\begin{array}{l}J_{0} \\
\stackrel{\circ}{+}\end{array}$ \\
\hline & $\sum_{\sum}^{\infty}$ & $\begin{array}{l}+ \\
\infty \\
0 \\
0\end{array}$ & $\begin{array}{l}\approx \\
\tilde{0} \\
\tilde{0}\end{array}$ & 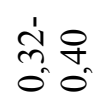 & ' & $\begin{array}{l}\circ \\
\text { n் }\end{array}$ \\
\hline & $\stackrel{O}{\xi}$ & $O_{0}$ & $\ddot{0}$ & $\ddot{0}$ & I & $\begin{array}{l}n \\
0 \\
0\end{array}$ \\
\hline & 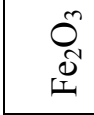 & $\begin{array}{l}n \\
n \\
n\end{array}$ & $\stackrel{\overbrace{}}{\sim}$ & $\begin{array}{l}\text { ì } \\
\tilde{o}^{\circ}\end{array}$ & $\mathfrak{o}^{n}$ & $\begin{array}{l}\circ \\
\stackrel{\infty}{\infty}\end{array}$ \\
\hline & 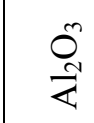 & $\begin{array}{l}8 \\
\stackrel{0}{ \pm}\end{array}$ & 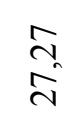 & 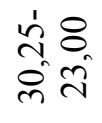 & & $\tilde{m}_{0}^{m}$ \\
\hline & $\stackrel{\overbrace{}}{\varrho}$ & $\stackrel{2}{0}$ & $\stackrel{2}{2}$ & $\stackrel{n}{m}=$ & , & $\begin{array}{l}n \\
0 \\
0 \\
0\end{array}$ \\
\hline & $\stackrel{\overbrace{}}{\circ}$ & $\begin{array}{l}\infty \\
\tilde{\sigma} \\
\tilde{\sigma}\end{array}$ & $\begin{array}{l}\delta \\
\text { on } \\
\text { in }\end{array}$ & 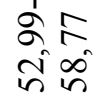 & 1 & $\stackrel{\infty}{\infty}$ \\
\hline \multicolumn{2}{|c|}{ 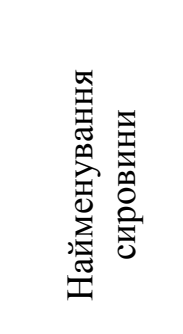 } & 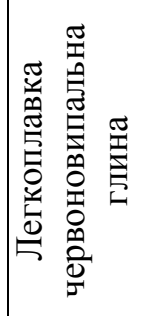 & 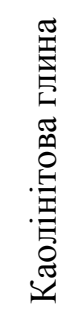 & 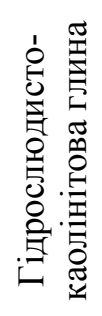 & 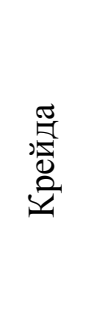 & 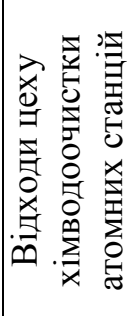 \\
\hline
\end{tabular}




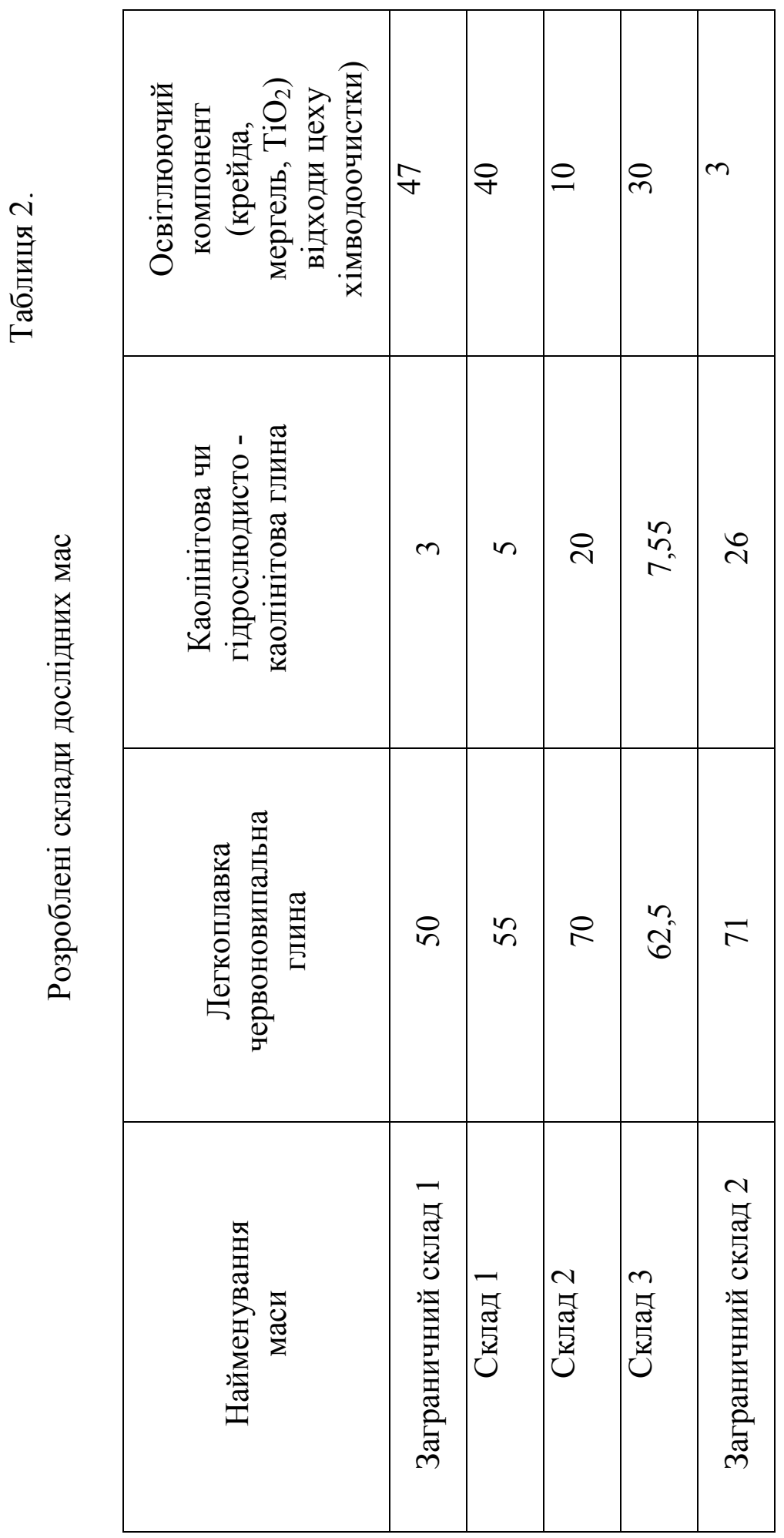




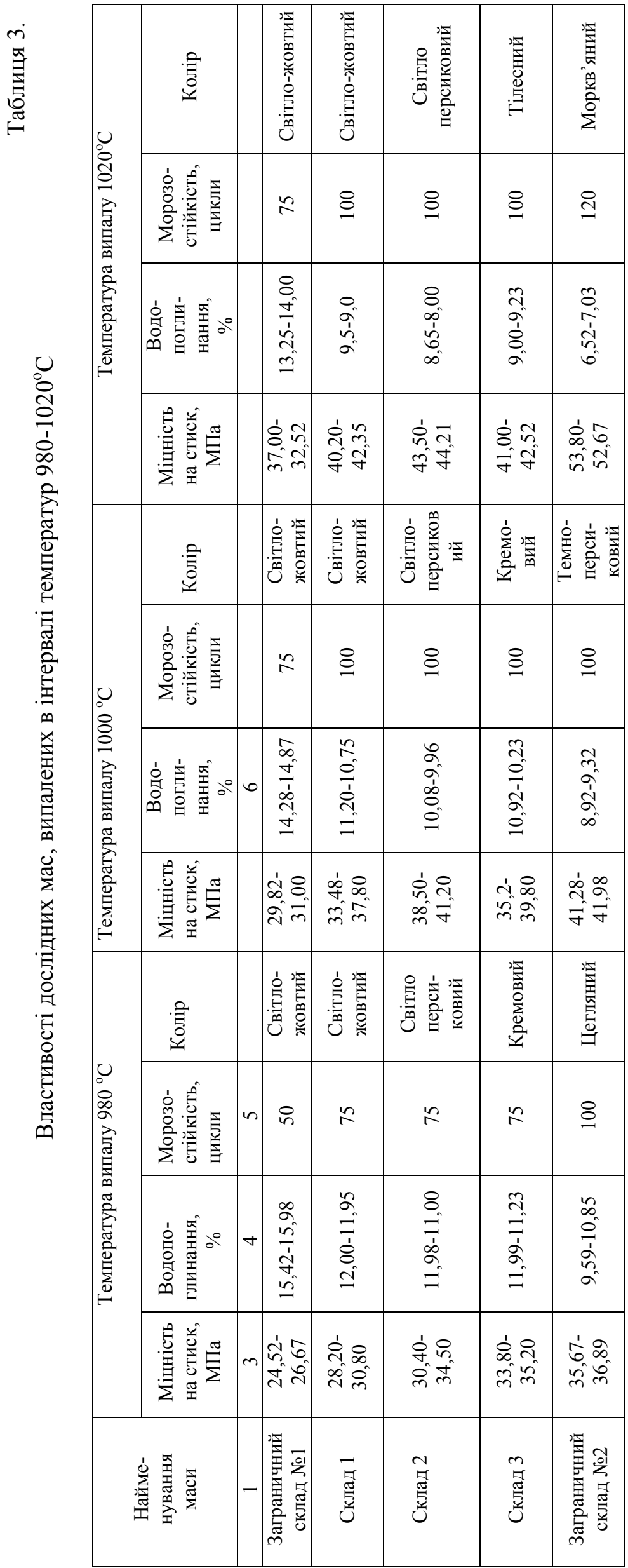


Додатки освітлюючих компонентів відрізняються вмістом $\mathrm{CaO}$, що впливає на колір цегли, отриманої із маси, що заявляємо. Чим більше вміст $\mathrm{CaO}$, тим світлішу окраску цегли отримуємо. За рахунок використання карбонатвмістких додатків з різним вмістом $\mathrm{CaO}$ ми розширюємо кольорову гаму лицьової керамічної цегли, що отримуємо на основі розробленої керамічної маси.

Додатки матеріалів, що освітлюють (мергель, крейда, відходи цеху хімводоочистки атомних станцій), каолінітові та гідрослюдисто-каолінітові глини в композиції 3 легкоплавкою червоновипальною глиною при даному співвідношенні компонентів формують оптимальну кристалізаційну структуру. На основі сформованої оптимальної кристалізаційної структури, яка одержана при вказаному співвідношенні компонентів, отримано кращі фізико-технічні властивості: більша міцність на стиск та морозостійкість при меншому водопоглиненні керамічної лицьової цегли. Використання даних компонентів при вказаному співвідношенні обумовлює також появу деякої кількості рідкої фази при випалі, що сприяє інтенсифікації спікання керамічної маси складів (таблиці 2, 3) при зниженні температури на $30-50{ }^{\circ} \mathrm{C}$.

Технологічна схема отримання керамічної маси наступна: шихта для виготовлення цегли світлих тонів отримується шляхом подрібнення глини та додатків на каскаді вальців 3 використанням вальців супертонкого помелу ( $<0,8$ мм) (таблиця 3$)$. При необхідності можливо використовувати бігуни для подрібнення шихти. Шихта вилежується в шихтосховищі протягом 7 - 14 діб 3 подальшим формуванням на вакуум-пресах пластичної, жорсткої та полужорсткої екструзії, сушкою виробів в тунельній чи камерній сушарці та випалом в тунельній печі при максимальній температурі випалу $980-1000{ }^{0} \mathrm{C}$.

3 ціллю усунення грудкування карбонатвмістких добавок на каскаді валків можливо використовувати сухе змішування каолінітової чи гідрослюдисто - каолінітової глини 3 карбонатвмісткими додатками. При цьому агрегати карбонатвмістких добавок розподіляються між агрегатами каолінітової чи гідрослюдисто-каолінітової глини, що запобігає грудкуванню карбонатвмістких компонентів. Таким чином ми збільшуємо ефективність подальшого помелу на каскаді валків до тонини помелу менше ніж 0,8 мм та однорідності керамічної суміші.

Для запобігання такого виду браку, як “дутик”, з ціллю повного розкладу $\mathrm{CaCO}_{3}=$ $\mathrm{CaO}+\mathrm{CO}_{2}$, що вноситься в дослідну шихту карбонатвмісткими добавками, в інтервалі температур 720-980 ${ }^{\circ} \mathrm{C}$. необхідно передбачити ізотермічну видержку від 2 до 5 годин в залежності від складу керамічної шихти.

Завдяки цьому, отримані вироби характеризуються однорідною, бездефектною поверхнею світлих тонів.

Техніко-економічна ефективність впровадження даної розробки у виробництві 
будівельної кераміки обумовлюється виробництвом керамічної цегли широкої кольорової гами (жовтого, тілесного, кремового та персикового кольору) для обличкування фасадів при низькотемпературному випалі $\left(980-1000^{\circ} \mathrm{C}\right)$, за рахунок чого зменшуються витрати газу на випал виробів.

\section{Висновки}

1. В основу розробки поставлено задачу збільшення міцності на стиск та морозостійкості керамічної цегли світлих тонів, що отримується на основі червоновипальних глин та освітлювальних додатків, при зменшенні водопоглинення та зниженні енерговитрат на виробництво, у тому числі і зниження температури випалу на 30-50 ${ }^{\circ} \mathrm{C}$ шляхом використання додатково каолінітової та гідрослюдисто-каолінітової глини при наступному співвідношенні компонентів, мас, \% (по сухій речовині)

Легкоплавка червоновипальна

глина $-55-70 \%$

Освітлюючі добавки

(крейда, мергель, $\mathrm{TiO}_{2,}$ відходи цеху хімводочистки

атомних станцій )

$$
\begin{aligned}
& -5-40 \% \\
& -5-25 \%
\end{aligned}
$$

каолінітова, гідрослюдисто-каолінітова глина

2. Використання даної керамічної маси дозволяє знизити температуру випалу лицьової керамічної цегли світлих тонів до 980 - $1000{ }^{\circ} \mathrm{C}$ при отриманні високих фізикотехнічних показників за рахунок використання каолінітової чи гідрослюдисто-колінітової глини в композиції 3 легкоплавкою червоновипальною глиною та освітлюючими добавками при даному співвідношенні компонентів

3. 3 метою усунення грудкування карбонатвмістких добавок на каскаді валків передбачається додаткове сухе змішування та зберігання каолінітової чи гідрослюдистокаолінітової глини 3 карбонатвмісткими додатками і 3 подальшим вилежуванням керамічної маси в шихтосховищі.

4. 3 метою повного розкладу $\mathrm{CaCO}_{3}$, що вноситься в шихту карбонатвмісткими добавками (п.1.) при випалі керамічної цегли світлих тонів в інтервалі температур 720 $980^{\circ} \mathrm{C}$, необхідно передбачити ізотермічну витримку від 2 до 5 годин.

5. Розроблена керамічна маса для виробництва обличкувальної лицьової та клінкерної цегли та інших архітектурно-оздоблювальних керамічних виробів характеризується високими фізико-технічними показниками та різними відтінками світлих кольорів: світло-жовтим, світло-персиковим, кремовим, тілесним. 


\section{Перелік посилань}

1. Альперович И.А. Производство лицевого глиняного кирпича. Обзорная информация М.: ВНИИЭСМ. - 1978. - С. 14-17.

2. Г. Зальманг. Физические и химические основы керамики. ОНТИ-ХИМТЕОРЕТ. - Л.: 1935. $-286 \mathrm{c}$.

3. Лундина М.Г. Добавки в шихту при производстве керамических стеновых материалов. Обзорная информация ВНИИЭСМ, М.,1974,c.70-71.

4. Альперович И.А., Смирнов А.В. Лицевой керамический кирпич обьемного окрашивания в современной архитектуре. Строительные материалы. - 1990. - №12. - С. 46.

5. Альперович И.А. Новое в технологии лицевого керамического кирпича обьемного окрашивания.. Строительные материалы 1993. - №7 С. 5-9.

6. Рыбьев И.А.,Серегин А.А.,Скрыльников Д.К.Способ изготовления лицевого кирпича. А.с. 874710 опубл.23.10.81.БИ №39.

7. Патент RU 2266878 C2 от 18. 02. 2004г. Способ изготовления строительной керамики светло-желтого цвета и ее состав / Вакалова Т.В., Погребенков В.М., Рева И.Б. заявка $2004104955 \backslash 03$ от 18.02.2004 г.; дата опубликования заявки 27.12.2005. Бюл. №36. 